\title{
Transitional jobs after release from prison: effects on employment and recidivism
}

\author{
Erin Jacobs Valentine ${ }^{*}$ and Cindy Redcross
}

\author{
* Correspondence: \\ Erin.Valentine@mdrc.org \\ MDRC, 16 East 34 Street, New York, \\ NY 10016, USA
}

\begin{abstract}
This paper presents the results of two experimental evaluations of transitional jobs programs for recently released former prisoners: the Evaluation of the Center for Employment Opportunities (CEO) and the Transitional Jobs Reentry Demonstration (TJRD). The analysis assesses the effects of these programs on employment and recidivism. We find that the programs in both studies led to a large increase in employment driven by the transitional jobs themselves. However, the programs did not increase employment in non-program jobs. In addition, the CEO transitional jobs program reduced recidivism, but the TJRD programs did not. These results have implications for policy and research.

JEL Classification Code: J24

Keywords: Recidivism; Employment; Transitional jobs programs; Random assignment; Reentry
\end{abstract}

\section{Introduction}

Beginning in the 1970s, the number of people incarcerated in the United States increased dramatically, reaching historically unprecedented levels (Western 2006). Today, more than 2 million people are incarcerated in federal and state prisons and local jails (Glaze and Kaeble 2014), and more than 600,000 people are released from state and federal prisons each year (Carson and Golinelli 2014).

People who are released from prison often face daunting obstacles, such as problems finding housing, reconnecting with family, and avoiding substance abuse, as they move back to their communities. On top of the other obstacles they face, many former prisoners have great difficulty finding steady work. Many are hampered by low levels of education, poor work experience, or health problems that make it difficult for them to find work (Western 2006). They also face employer discrimination based on their criminal record (Pager 2007).

In addition to experiencing poor labor market outcomes, former prisoners are very likely to recidivate, or return to crime (Durose et al. 2014). Many experts believe that one cause of high recidivism rates is the poor labor market outcomes experienced by former prisoners; employment is therefore considered an especially important outcome, key to helping former prisoners make a successful transition back to society without returning to crime.

(C) 2015 Valentine and Redcross. Open Access This article is distributed under the terms of the Creative Commons Attribution 4.0 International License (http://creativecommons.org/licenses/by/4.0/), which permits unrestricted use, distribution, and reproduction in any medium, provided you give appropriate credit to the original author(s) and the source, provide a link to the Creative Commons license, and indicate if changes were made. 
The prisoner reentry issue has attracted increasing attention in recent years, and a number of states have launched multifaceted prisoner reentry initiatives. The federal government has provided special funding to support these efforts through the Serious and Violent Offender Reentry Initiative, the Prisoner Reentry Initiative, and, most recently, the Second Chance Act of 2008. However, there is very little reliable evidence about which types of employment services, if any, are effective for former prisoners. Despite a long history of research in the criminal justice field, including many experimental evaluations, there have been few rigorous studies of employment focused reentry models.

One program model that is seen as promising is one that provides transitional jobs, or temporary paid work, coupled with job search assistance, case management, or other wraparound services. Transitional jobs programs are expected to lead to better longterm employment outcomes for former prisoners by improving soft skills and building work history. In turn, improved employment outcomes are expected to lead to reductions in recidivism.

Between 2004 and 2012, MDRC led two large-scale evaluations of transitional jobs programs targeting individuals returning from prison. In this paper, we present the results of these two evaluations: the Evaluation of the Center for Employment Opportunities (CEO) and the Transitional Jobs Reentry Demonstration (TJRD). Both evaluations employ an experimental design in which individuals were randomly assigned to a program group, which was offered a transitional jobs program, or to a control group, which was offered a basic job search assistance program. The analysis assesses the effects of these programs on employment and recidivism outcomes.

Not surprisingly, we find that the transitional jobs programs in both studies led to a large increase in employment, driven by the transitional jobs, during the program period. The CEO program also generated small increases in non-program jobs in some post program quarters. However, overall, neither the CEO nor the TJRD transitional jobs programs led to consistent increases in employment in non-program jobs. With regard to recidivism, the results from the two studies differ. While the CEO transitional jobs program reduced recidivism, the TJRD programs did not. Differences between the CEO and TJRD program models may help to explain these results, which have important implications for policy and future research.

\subsection{Labor market outcomes and recidivism of former prisoners}

Former prisoners occupy an especially disadvantaged position in the labor market, partly because of characteristics they had prior to being incarcerated and partly because their contact with the criminal justice system has further damaged their job prospects. Compared with the general population, individuals who go to prison average low levels of educational attainment (Harlow 2003), low cognitive skills (Petersilia 2005; Western 2006), and poor work histories (Petersilia 2005; Travis 2005). These human capital deficits make it difficult to obtain employment, especially given increasing demands for highly educated and skilled workers and a shrinking pool of well-paying jobs for lowskilled workers (Bernhardt et al. 2001; Morris and Western 1999). Former prisoners are also comprised disproportionately of non-white men, whom employers are especially reluctant to hire, particularly for the service sector jobs that form the majority of work available to low-skilled workers (Holzer 2009; Pager 2003). 
A criminal record and time spent in prison further damages the employment prospects of individuals leaving prison. Both employer surveys and audit studies have consistently shown that employers discriminate against those with a criminal record (Holzer et al. 2004; Pager 2003; 2007). This problem has worsened as the use of criminal background checks has become more widespread (Stoll and Bushway 2008). Furthermore, time spent in prison can hinder an individual's ability to find work by making it difficult to build additional work experience and by eroding job skills and social ties that may connect individuals to employment (Western 2006; Western et al. 2001). Moreover, in many states, convicted felons are legally barred from specific occupations. Not surprisingly, employment rates among former prisoners are very low following release (Visher and Kachnowski 2007).

In addition to experiencing poor labor market outcomes, former prisoners recidivate at high rates. According to the latest national estimates, two-thirds of individuals released from prison are re-arrested within three years of release, while about half return to prison, either because of a new crime or because they have violated conditions of parole (Durose et al. 2014). Crime rates among former prisoners are far higher than those among the general population (Raphael and Stoll 2004).

Many scholars speculate that poor labor market outcomes are one of the primary factors driving the high rates of recidivism among former prisoners, as employment is often theorized to be important to successfully reintegrating into the community after release (see, for example, Weiman et al. 2007; Western 2008; Uggen et al. 2005). There are several mechanisms through which employment can be expected to reduce participation in crime. For example, social bonds that develop with coworkers and employers may provide informal social controls that reduce an individual's likelihood of participating in crime (Sampson and Laub 1993). Employment may also exert an effect on criminal activity by simply reducing the amount of time an individual can spend associating with others who are involved in crime (Warr 1998). In addition, former prisoners who receive income through employment may have less incentive to obtain money or goods through crime, reducing their likelihood of recidivating (Ehrlich 1973; Grogger 1998).

Despite theoretical support, strong evidence backing this conjecture is lacking. While employment and crime are generally found to be negatively correlated (Laub and Sampson 2001; National Research Council 2008), the evidence that employment is causally related to recidivism is far from conclusive. Most of the empirical work in this area cannot rule out the possibility that the relationship between employment and crime is spurious (Bushway and Reuter 2002; Laub and Sampson 2001) or that these studies are in fact measuring the effect of crime on employment (Hagan 1993).

\subsection{Transitional jobs programs for former prisoners}

Transitional jobs programs provide temporary paid jobs, support services such as case management, and job placement help to hard-to-employ individuals. The transitional jobs model emerged in the 1990s in the welfare system, but its roots stretch back to a number of different subsidized employment models that have been implemented or tested in the past (Bloom 2010).

The transitional jobs model is designed to teach participants soft skills in a hands-on work environment. The model assumes that many people would have better labor market outcomes if they had the soft skills required to obtain a job or to function well in a 
work environment and that people are best able to learn to work by working. By placing participants into temporary jobs in a program environment, program staff are able to identify and address workplace problems such as tardiness or difficulty taking direction that would likely lead to dismissal in a regular job. Thus, the model is designed to teach the vital soft skills that many employers say they value most. It is also assumed that employers will be more likely to hire someone who has performed well in a job environment for several weeks or months.

In recent years, transitional jobs programs have increasingly targeted former prisoners. In the reentry context, the transitional jobs are designed to serve three purposes: (1) the jobs provide stability and income, which may reduce the incentive to turn back to crime in the critical period just after release; (2) the experience of working in a transitional job may teach participants how to work; and (3) time spent working in the transitional job may be a positive signal to employers. The soft skills learned in the transitional jobs may make participants more appealing to employers by demonstrating that the individuals were able to show up to work on time and could perform satisfactorily in the program jobs. Employers might then be more willing to overlook a criminal background and hire the program participants. Participants might also be better equipped for the regular labor market, which, in turn, could make them more likely to hold a job. The model assumes that better employment outcomes will help deter future recidivism.

The first rigorous test of a transitional, subsidized employment model for former prisoners was the National Supported Work Demonstration, which ran from 1975 to 1980 (MDRC 1980). The Supported Work programs offered 12 to 18 months of highly structured paid work experience. Participants worked in crews to promote peer group support, and the model emphasized "graduated stress," that is, expectations at the work site were supposed to increase over time until they approximated the expectations in a regular, non-program job. Almost all the programs helped participants find regular jobs, though the intensity and quality of this assistance varied. Some of the Supported Work programs were "social enterprises" that sold products or services to partly offset the costs of running the program.

Supported Work was tested for four hard-to-employ groups, including individuals who had been incarcerated in the prior six months. The sample included about 2,300 former prisoners ( $94 \%$ male) across seven sites. The program initially generated large increases in employment and earnings during the program period (the initial period, when many participants were working in transitional jobs), but there was little evidence of longer-term effects on employment or earnings. Overall, there were no effects on recidivism except for some reductions among participants who were older than 26 years of age, perhaps because they had reached a point in their lives when they were determined to avoid further incarceration and the jobs program helped them further this goal (Uggen 2000).

\subsection{Interventions}

This paper reports on the findings from two experimental evaluations of transitional jobs programs for former prisoners conducted by MDRC between 2004 and 2012. The first, the Evaluation of the Center for Employment Opportunities (CEO), ${ }^{1}$ tested the effects of CEO's transitional jobs reentry program in New York City (Redcross et al. 2009; 
2012). The second evaluation, the Transitional Jobs Reentry Demonstration (TJRD), ${ }^{2}$ tested the effects of transitional jobs reentry programs in four cities in the Midwest: Chicago, Detroit, Milwaukee, and Minneapolis-St. Paul (Redcross et al. 2010; Jacobs 2012). As we explain in more detail below, both the CEO and TJRD evaluations used a random assignment research design to determine whether a transitional jobs program, offering transitional jobs and other services, is more effective than a basic job search assistance program.

The CEO transitional jobs program provided temporary paid jobs and other services in an effort to improve participants' labor market prospects and reduce the odds that they would return to prison. CEO's model began with a short pre-employment class lasting five days. Once participants completed the class, they were placed immediately into a transitional job in one of CEO's work crews. Crews of about six participants worked in city and state agencies throughout New York City and were supervised by a CEO staff person. During the study period, participants worked seven hours a day, four days per week, and were paid each day for the work performed that day. The type of work performed on the work crews was not designed to teach skills for a specific occupation but, instead, was geared toward teaching the soft skills that employers value, such as how to show up to work on time and how to behave on the job. On the fifth day of each week, participants reported to CEO's office and met with their job coaches (case managers) and job developers. They could also participate in other services, such as a fatherhood program and parenting classes. Once deemed job-ready, participants got help finding a permanent job.

The TJRD transitional jobs programs in the four Midwestern sites were all structured somewhat differently, but there were some basic elements that all programs adopted. All provided participants with temporary, minimum wage jobs that offered 30 to 40 hours of paid work each week. As in the CEO study, the transitional jobs provided to participants were not focused on building skills in any particular occupation, but all aimed to identify and address behavior or performance issues that emerged at the work sites. All provided a range of ancillary services and supports to participants, and all helped participants look for non-program jobs to follow the transitional jobs, often with the help of job developers who approached employers to identify job openings for participants. The Milwaukee program and, during part of the study period, the Minneapolis-St. Paul program also offered participants retention bonus payments for getting and holding non-program jobs. The payments could total up to $\$ 1500$ or so over six to nine months.

The Detroit and Minneapolis-St. Paul transitional jobs programs were operated by Goodwill Industries affiliates, and participants worked in jobs in existing Goodwill enterprises such as retail stores or a light manufacturing plant. ${ }^{3}$ In Chicago, transitional jobs workers were employed by a staffing agency established by the Safer Foundation. The staffing agency contracted with a major waste management firm that in turn had contracts with the City of Chicago to operate garbage recycling plants; almost all program participants worked in those plants. Finally, the New Hope program in Milwaukee used a scattered site model; participants were placed in positions with local nonprofit organizations or small businesses but were employed by New Hope, which paid their wages.

\subsection{Research design, data, and methods}

Both the CEO and TJRD evaluations aim to determine whether a transitional jobs program, offering transitional jobs and other services, is more effective than a basic job 
search assistance program. The evaluations were designed as rigorous, experimental studies whereby former prisoners were assigned, at random, to one of two research groups:

Program group. Individuals who were assigned to the program group were offered a transitional jobs program in their city. This program included a transitional job and other support services, such as pre-employment classes, job coaching, job search assistance, job development, and post-placement services.

Control group. Individuals who were randomly assigned to this group were referred to the job search program in their city and were offered basic job search and placement assistance but were not offered a transitional job.

The control group in the CEO study was offered very basic services, which were also provided by CEO. Members of this group were offered a shorter version of CEO's preemployment class and were given access to a resource room with basic job search equipment, such as computers and fax machines. A staff person was available to assist them with aspects of the job search if needed. The control group in the TJRD study was offered more robust services. These varied across sites, but at a minimum, all of the TJRD job search programs helped participants prepare a résumé, learn how to fill out job applications and interview for jobs (including how to answer questions about their convictions), and identify job leads. Most of these programs offered group job readiness classes and case managers, who were available to meet with participants. In the TJRD study, the job search programs were run by the Safer Foundation in Chicago, JVS and the Detroit Hispanic Development Corporation in Detroit, Project RETURN in Milwaukee, and the Amherst H. Wilder Foundation in Minneapolis-St. Paul.

Sample members in the TJRD study included former prisoners who had been released from prison recently - that is, within the three months before study enrollment-while the full CEO sample included both recently released former prisoners and those who had been out of prison longer. In order to make the results as comparable as possible, this paper only presents information for the recently released subgroup of CEO sample members.

For CEO, study enrollment was conducted between January 2004 and October 2005 and resulted in a sample of 977 former prisoners, but as mentioned above, the analysis presented in this paper is focused on the 385 recently released sample members: 225 in the program group and 160 in the control group. For TJRD, study enrollment was conducted between January 2007 and September 2008 and resulted in a sample of 1,813 recently released former prisoners: 912 in the program group and 901 in the control group.

Because the studies' sample members were assigned at random to one research group or the other, the two groups, on average, were similar on all personal characteristics at the start of the study. Therefore, one can be confident that any statistically significant differences in outcomes that emerge between the groups over time can be attributed to the effects of the transitional jobs programs over and above the basic job search assistance programs. That is, if assignment to the program group significantly predicts employment or recidivism outcomes during the follow-up period, we can conclude with a high level of confidence that the transitional jobs programs affected those outcomes. 
All analyses use an "intent-to-treat" framework that compares the outcomes for all program group members with the outcomes for all control group members, regardless of whether they participated in the program that they were offered.

To measure the effect of the transitional jobs programs on each outcome, we estimate a multivariate regression model to measure the size and significance level of the coefficient on experimental group status, controlling for pre-random assignment characteristics. The use of regression adjustment neutralizes chance differences in characteristics between the program and control groups and also increases the power of the statistical tests for effects. We estimate regression models of the following form, using ordinary least squares:

$$
Y_{i}=\alpha+\beta P_{i}+\delta X_{i}+\varepsilon_{i},
$$

where $Y_{i}=$ the outcome measure for sample member $i, P_{i}=$ one for program group members and zero for control group members, $X_{i}=a$ set of background characteristics for sample member $i, \varepsilon_{i}=a$ random error term for sample member $i, \beta=$ the estimate of the average effect of the program on the outcome, $\alpha=$ the intercept of the regression, and $\delta=$ the set of regression coefficients for the background characteristics.

Data for the TJRD and CEO samples were collected from a number of sources. First, at baseline, sample members were asked to fill out a short survey just before they were randomly assigned. The baseline surveys for the two studies differed somewhat but collected much of the same information, including race and ethnicity, marital status, housing situation, children of the respondent, child support orders, educational attainment, and employment history. All sample members completed a baseline survey. In the CEO study, a follow-up survey was administered to a portion of sample members an average of 20 months after they entered the study. The survey asked questions about service receipt, employment, housing, drug treatment, family relationships, and other issues. The response rate for the survey was about $68 \%$.

We measure employment and recidivism outcomes using administrative data collected from the labor department and criminal justice agencies in each state. The employment data consist of quarterly unemployment insurance (UI) earnings records. For both studies, two types of criminal justice data were collected. First, either the state police or the criminal information repository in each state provided arrest and conviction history data. ${ }^{4}$ Second, state prison incarceration data were collected from either the department of corrections or the criminal information repository in each state. $^{5}$ Finally, for the CEO sample only, local jail incarceration data were collected from the New York City Department of Correction. ${ }^{6}$ For CEO, the follow-up data cover three years after random assignment for each sample member, while for TJRD, two years of follow-up data are available.

\subsection{Sample characteristics}

Both studies targeted former prisoners. All individuals in the CEO sample were on parole, and nearly all individuals in the TJRD sample were on parole or another type of community supervision. Because of the way individuals were recruited for these studies, the TJRD and CEO samples are not random samples of individuals returning from prison to the five study cities. All sample members chose to participate in the studies in order to gain access to a transitional jobs program or a job search program (in CEO, 
all individuals were referred to CEO by their parole officers, but study participation was still voluntary). This suggests that the sample may include a disproportionate number of releasees who were actively pursuing legal work and who had a relatively high motivation to work. At the same time, the fact that all sample members were unemployed at baseline indicates that the sample is not likely to include those who already had work lined up when they were released or who found employment right away. This suggests that this sample may be both relatively motivated to work and relatively disadvantaged compared to all parolees in these cities. Selection into the study may also have occurred based on other factors, such as the preferences of particular parole officers. Because these studies do not use random samples, the extent to which the results can be generalized to other former prisoners is not clear. However, these samples are similar on measurable characteristics to prisoners released to urban areas generally.

Table 1 presents selected background characteristics of the CEO and TJRD research samples. These characteristics are based on information collected from sample members just before random assignment, as well as on criminal justice administrative records. Most of the sample members are African-American or Hispanic. All TJRD sample members were men, while a small percentage of CEO sample members were women. Both samples were about 34 years old, on average, when they enrolled in the study. Both sets of sample members had low levels of educational attainment, though the CEO sample was somewhat more disadvantaged in that respect. About 55\% of CEO sample members had at least a GED or high school diploma, while this was true for about $69 \%$ of TJRD sample members. Many sample members also had weak employment histories. About $80 \%$ or more had worked in the past, but only between 50 and $60 \%$ had worked six consecutive months for a single employer. Sample members for both studies also had extensive histories with the criminal justice system, averaging more than seven arrests, three felony convictions, and five to six years in state prison.

\section{Results}

\subsection{Effects on employment and earnings}

The analyses show that the effects of the transitional jobs programs on employment and earnings were similar for the two studies. ${ }^{7}$ Figure 1 illustrates the effects of the transitional jobs programs on overall employment, which includes both the transitional jobs and all other UI-covered employment in study states. Results for CEO appear in the top graph, while results for TJRD appear in the bottom graph. Each of these two graphs shows the employment rates for the program and control groups in each quarter following random assignment-that is, the adjusted proportion of each research group who worked for at least one day in a given quarter. In both cases, being offered a transitional jobs program substantially increased employment early in the follow-up period, but the effect faded as program group members left the transitional jobs. As discussed in more detail below, there were some small effects of the CEO transitional jobs program on overall employment in some quarters late in the follow-up period.

Figure 2 shows quarterly rates of employment in non-program jobs only. Again, results for the CEO study are shown in the top graph, while results for the TJRD study are shown in the bottom graph. A comparison between the graphs in Fig. 1 and the 
Table 1 Selected baseline characteristics of CEO and TJRD sample members

\begin{tabular}{|c|c|c|}
\hline Characteristic & CEO Sample & TJRD Sample \\
\hline Average age (years) & 33.6 & 34.6 \\
\hline \multicolumn{3}{|l|}{ Race/ethnicity (\%) } \\
\hline White, non-Hispanic & 1.8 & 10.2 \\
\hline Black, non-Hispanic & 64.2 & 80.7 \\
\hline Hispanic & 31.3 & 4.7 \\
\hline Other & 2.6 & 4.3 \\
\hline Male (\%) & 94.5 & 100.0 \\
\hline \multicolumn{3}{|l|}{ Education (\%) } \\
\hline High school diploma & 10.9 & 22.8 \\
\hline General Educational Development (GED) certificate & 44.1 & 46.2 \\
\hline Beyond high school & 5.9 & 5.8 \\
\hline None of the above & 39.1 & 25.2 \\
\hline \multicolumn{3}{|l|}{ Employment History } \\
\hline Ever any employment (\%) & 79.1 & 86.5 \\
\hline Employed 6 consecutive months for one employer (\%) & 58.4 & 52.6 \\
\hline \multicolumn{3}{|l|}{ Criminal History } \\
\hline Average number of arrests $^{\mathrm{a}}$ & 7.9 & 9.2 \\
\hline Number of prior felony arrests & 4.8 & 3.9 \\
\hline Number of prior misdemeanor arrests & 3.0 & 2.7 \\
\hline Average number of prior convictions ${ }^{b}$ & 7.0 & 4.1 \\
\hline Number of prior felony convictions & 2.7 & 2.6 \\
\hline Number of prior misdemeanor convictions & 4.0 & 1.0 \\
\hline Lifetime number of months in state prison ${ }^{c}$ & 62.7 & 71.4 \\
\hline Sample size & 385 & 1,813 \\
\hline
\end{tabular}

In the CEO evaluation, MDRC calculations were based on data from the CEO Baseline Information Form and the New York State Division of Criminal Justice Services (DCJS). In the TJRD evaluation, MDRC calculations were based on the Baseline Information Form and data from Michigan State Police, Minnesota Bureau of Criminal Apprehension, State of Wisconsin Department of Justice, Illinois Criminal Justice Information Authority, and the Department of Corrections in each state Data in this table are unweighted

${ }^{a}$ Each arrest date is counted only as a single event. If there are multiple crimes or charges on the same date, only the most serious charge is recorded in the analysis

${ }^{b}$ Each conviction date is counted only as a single event. If there are multiple convictions on the same date, only the most serious charge is recorded in the analysis. The total includes convictions for felony, misdemeanor, and other crime classes

"Lifetime" includes historical data as early as 1970 for the CEO sample and as early as 1980 for the TJRD sample

graphs in Fig. 2 indicates that the early, positive effects on overall employment were driven entirely by the transitional jobs, as there were few significant, positive effects on non-program employment. Early in the follow-up period, especially for the TJRD sample, program group members were less likely to be employed in non-program jobs than control group members. This occurred because some program group members who would otherwise have been able to find regular employment instead worked in a transitional job. In other words, they temporarily substituted the transitional job for regular employment. This pattern was expected, given the ready availability of transitional jobs for program group members. We find a similar pattern of results, though to a smaller degree, among the CEO sample.

Ultimately, the transitional jobs programs aimed to affect longer-term employment after the program period when program group members were no longer working in 

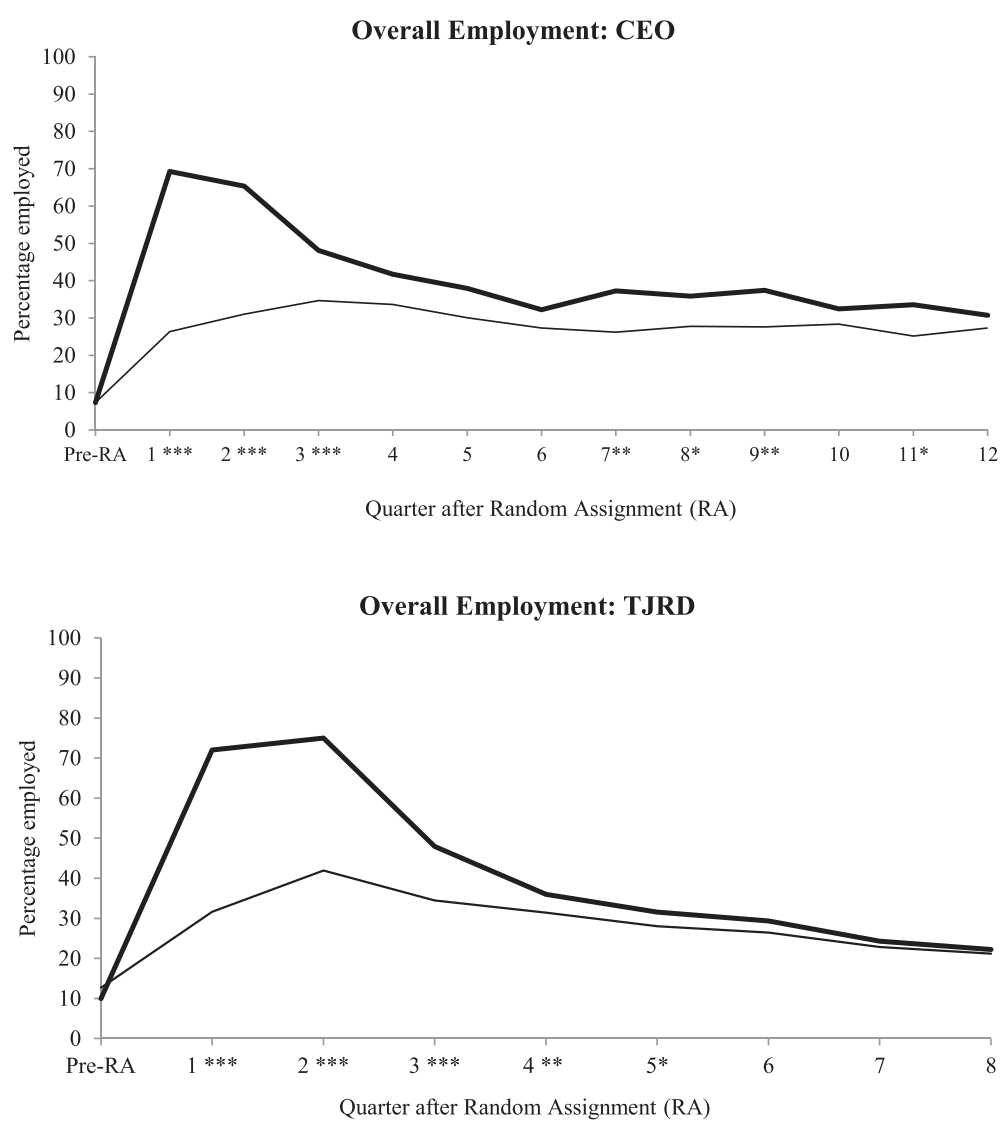

Fig. 1 Quarterly Impacts on Overall Employment. Legend: - Program Group, — Control Group. SOURCES: In the CEO evaluation, MDRC calculations were based on unemployment insurance (UI) wage records from New York State. In the TJRD evaluation, MDRC calculations were based on payroll data from each site and unemployment insurance (UI) wage records from each of the states in the demonstration (Illinois, Michigan, Minnesota, and Wisconsin). NOTES: Results in this figure are weighted by week of random assignment and adjusted for pre-random assignment characteristics. Statistical significance levels are indicated as: ${ }^{* *}=1 \%$; ${ }^{* *}=5 \% ;{ }^{*}=10 \%$. Results in this table are regression-adjusted for pre-random assignment characteristics. For the TJRD sample, the pre-RA quarter includes only data for Illinois and Wisconsin because complete UI wage records were not available for Michigan and Minnesota. Random assignment took place in Quarter 1. The follow-up period for CEO sample members was three years post-random assignment. The follow-up period for TJRD was two years post-random assignment

transitional jobs. While participants worked in the transitional jobs, the programs worked to address workplace behaviors and performance issues that might affect later employment. They also provided job search and job placement assistance to move participants into non-program employment after the transitional job. Through these services, the programs hoped to affect long-term, non-program employment.

As the results in Fig. 2 show, the transitional jobs programs generally did not have this effect. There were no significant effects on non-program employment for the TJRD sample throughout the follow-up period. However, late in the second year and into the third year, statistically significant effects on non-program employment emerged among the CEO sample in some of the quarters. Given the timing of these effects, it is unlikely that they are direct effects of the CEO program, as program group members were no longer receiving employment services. A more plausible hypothesis is that the program's effects on incarceration (discussed below) led, by definition, to more control 

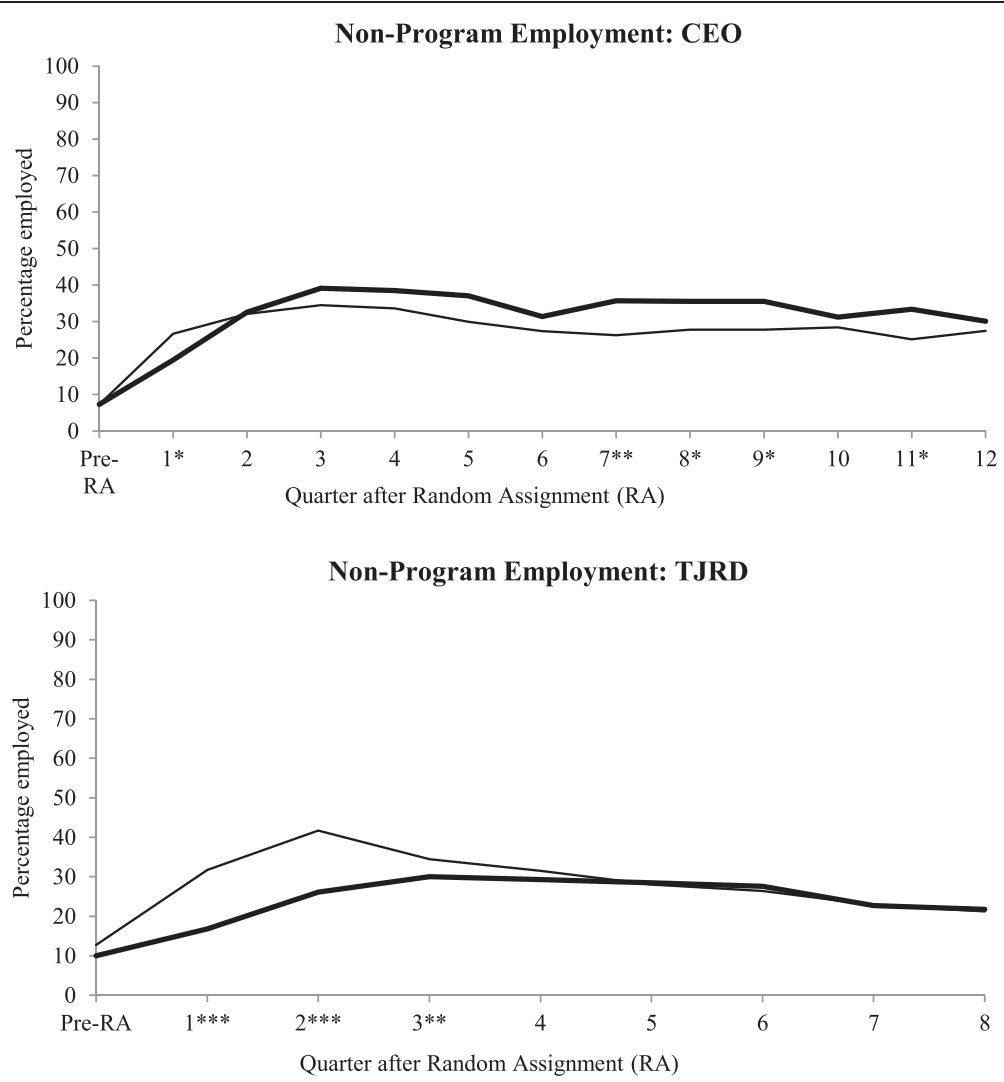

Fig. 2 Quarterly Impacts on Non-Program Employment. Legend: - Program Group, - Control Group. SOURCES: MDRC calculations using payroll data from each site and unemployment insurance (UI) wage records from each of the states in the demonstration (Illinois, Michigan, Minnesota, and Wisconsin). NOTES: Statistical significance levels are indicated as follows: ${ }^{* *}=1 \%$; ${ }^{* *}=5 \%$; ${ }^{*}=10 \%$. Results in this table are regression-adjusted for pre-random assignment characteristics. For the TJRD sample, the pre-RA quarter includes only data for Illinois and Wisconsin because complete UI wage records were not available for Michigan and Minnesota. Random assignment took place in Quarter 1. The follow-up period for CEO sample members was three years post-random assignment. The follow-up period for TJRD was two years post-random assignment

group members being incapacitated during this time and therefore unable to work. In other words, program group members were more likely to be out in the community and to have the opportunity to work. In the end, these effects are small and inconsistent across quarters.

\subsection{Effects on recidivism}

While the results for the CEO and TJRD studies are similar with regard to effects on employment and earnings, the results for the two studies differ with regard to effects on recidivism. Table 2 presents the effects of the CEO and TJRD transitional jobs programs on measures of recidivism. As the right half of the table shows, the TJRD programs had no significant effects on key outcomes during the study follow-up period of two years. ${ }^{8}$ About $55 \%$ of the program group and $52 \%$ of the control group were arrested, and about $29 \%$ of the program group and $27 \%$ of the control group were ever convicted of a crime during the two-year follow-up period. Neither of these differences is statistically significant. Finally, about half of the sample members were admitted to prison. Most of the prison admissions were for technical parole violations, which 
Table 2 CEO and TJRD impacts on recidivism

\begin{tabular}{|c|c|c|c|c|c|c|c|c|}
\hline \multirow[b]{2}{*}{ Outcome } & \multicolumn{4}{|l|}{ CEO } & \multicolumn{4}{|l|}{ TJRD } \\
\hline & $\begin{array}{l}\text { Program } \\
\text { Group }\end{array}$ & $\begin{array}{l}\text { Control } \\
\text { Group }\end{array}$ & $\begin{array}{l}\text { Difference } \\
\text { (Impact) }\end{array}$ & $P$-Value & $\begin{array}{l}\text { Program } \\
\text { Group }\end{array}$ & $\begin{array}{l}\text { Control } \\
\text { Group }\end{array}$ & $\begin{array}{l}\text { Difference } \\
\text { (Impact) }\end{array}$ & $P$-Value \\
\hline$\overline{\text { Ever } \text { arrested }}{ }^{\mathrm{a}}(\%)$ & 49.1 & 59.1 & -10.0 & ${ }^{*} 0.056$ & 55.2 & 51.8 & 3.4 & 0.131 \\
\hline $\begin{array}{l}\text { Ever convicted of a } \\
\text { crime }^{b}(\%)\end{array}$ & 44.0 & 56.7 & -12.7 & ${ }^{* *} 0.014$ & 29.0 & 26.5 & 2.4 & 0.243 \\
\hline Convicted of a felony & 15.6 & 14.6 & 1.0 & 0.789 & - & - & - & - \\
\hline $\begin{array}{l}\text { Convicted of a } \\
\text { misdemeanor }\end{array}$ & 31.9 & 46.1 & -14.3 & $* * * 0.005$ & - & - & - & - \\
\hline Ever incarcerated ${ }^{c}(\%)$ & 60.2 & 71.3 & -11.2 & ${ }^{* *} 0.027$ & - & - & - & - \\
\hline Prison & 38.9 & 43.4 & -4.5 & 0.387 & 49.9 & 49.9 & 0.0 & 0.995 \\
\hline Jail & 56.7 & 71.4 & -14.7 & $* * * 0.004$ & - & - & - & - \\
\hline $\begin{array}{l}\text { Ever incarcerated for a } \\
\text { new crime (\%) }\end{array}$ & 26.5 & 35.4 & -8.9 & ${ }^{*} 0.061$ & - & - & - & - \\
\hline Prison & 11.2 & 12.5 & -1.4 & 0.685 & 13.7 & 12.0 & 1.7 & 0.265 \\
\hline Jail & 16.4 & 25.6 & -9.1 & ${ }^{* *} 0.030$ & - & - & - & \\
\hline $\begin{array}{l}\text { Ever incarcerated for a } \\
\text { technical parole/probation } \\
\text { violation (\%) }\end{array}$ & 38.5 & 39.8 & -1.3 & 0.801 & - & - & - & - \\
\hline Prison & 23.8 & 25.5 & -1.7 & 0.717 & 31.0 & 31.1 & -0.1 & 0.980 \\
\hline Jail & 34.2 & 35.1 & -0.9 & 0.856 & - & - & - & - \\
\hline Total days incarcerated & 213 & 247 & -34 & 0.234 & - & - & - & - \\
\hline Prison & 118 & 138 & -20 & 0.345 & 116 & 123 & -7 & 0.403 \\
\hline Jail & 95 & 109 & -14 & 0.334 & - & - & - & - \\
\hline $\begin{array}{l}\text { Ever arrested, convicted, } \\
\text { or incarcerated }^{d}(\%)\end{array}$ & 66.8 & 75.8 & -9.0 & ${ }^{*} 0.063$ & 69.9 & 70.5 & -0.6 & 0.768 \\
\hline $\begin{array}{l}\text { Incarcerated at end of the } \\
\text { follow-up period }(\%)\end{array}$ & 30.1 & 36.1 & -6.0 & 0.221 & - & - & - & - \\
\hline $\begin{array}{l}\text { Sample size (CEO total = } \\
\text { 385; TJRD total =1,809) }\end{array}$ & 225 & 160 & & & 910 & 899 & & \\
\hline
\end{tabular}

In the CEO evaluation, MDRC calculations were based on data from the New York State Division of Criminal Justice Services (DCJS) and the New York City Department of Correction (DOC). In the TJRD evaluation, MDRC calculations were based on data from Michigan State Police, Minnesota Bureau of Criminal Apprehension, State of Wisconsin Department of Justice, Illinois Criminal Justice Information Authority, and the Department of Corrections in each state Results in this table are weighted by week of random assignment and regression-adjusted for pre-random assignment characteristics

The follow-up period for CEO sample members was three years post-random assignment. The follow-up period for TJRD was two years post-random assignment

Data on incarceration in jail were not collected for the TJRD evaluation

In CEO, this measure includes all reasons for incarceration, such as sentences for new crimes, technical violations of parole, detainee (jail), and other admission reasons

Statistical significance levels are indicated as: ${ }^{* *}=1 \%$; $*{ }^{*}=5 \%$; $=10 \%$

${ }^{a}$ Each arrest date is counted only as a single event. If there are multiple crimes or charges on the same date, only the most serious charge is recorded in the analysis

bSome convictions may have been associated with an arrest that occurred prior to random assignment. These convictions are counted in the analysis as occurring after random assignment

'Subcategories may sum to more than the total due to multiple admissions per person during the follow-up period

${ }^{\mathrm{d}}$ This composite measure was created by combining three measures that are not mutually exclusive: arrest, conviction, and incarceration. Participants who were arrested and/or convicted, for example, were also incarcerated. The composite measure represents people who experienced one or more of these recidivism measures

encarceration status in the CEO evaluation based on Quarter 12 after random assignment; includes both prison and jail

occur when a parolee violates a condition of his release, such as abstaining from drugs, reporting to a parole officer, or being home by a specified curfew. About $31 \%$ of the sample were admitted for a technical parole violation, while about $14 \%$ of the program group and $12 \%$ of the control group were admitted for a new crime (not significantly different). 
As the left half of the table shows, the results for the CEO study are quite different for recidivism outcomes. The CEO program significantly reduced arrests, convictions, and incarceration. Program group members were 10 percentage points less likely than control group members to be arrested (49\%, compared with 59\%). Program group members were also significantly less likely to be convicted of a crime and were less likely to be re-incarcerated, with reductions of 13 and 11 percentage points, respectively (60\% of program group members were incarcerated, compared with $71 \%$ of control group members). Overall, the CEO transitional jobs program led to a 9 percentage point reduction in any type of recidivism (arrest, conviction, or incarceration) over the three year follow-up period. In summation, while the TJRD transitional jobs programs did not lead to reductions in recidivism among recently released former prisoners, the CEO transitional jobs program did so across a number of recidivism measures.

\section{Discussion}

The evaluations of the Center for Employment Opportunities (CEO) and Transitional Jobs Reentry Demonstration (TJRD) transitional jobs programs are two of the most rigorous tests of employment programs for former prisoners in recent years. Both evaluations provide good tests of the transitional jobs model for former prisoners.

Both the CEO and TJRD transitional jobs programs greatly increased employment during the program period, but this effect resulted almost entirely from the transitional jobs themselves. For the full samples, neither the CEO nor the TJRD transitional jobs programs consistently improved non-program employment or earnings during the program period or the post-program period. In other words, the results from the two studies provide little evidence that the transitional jobs programs led to substantial improvements in longer-term employment outcomes.

However, the results of the CEO study are promising in some key respects. The CEO transitional jobs program reduced recidivism, an effect that is difficult to achieve and has rarely been seen in rigorous evaluations like this one. In addition, although the program did not increase the percentage of program group members who were ever employed in a non-program job (not shown), there is some evidence that CEO increased the number of quarters with non-program employment during the post-program period. However, these effects were likely a byproduct of the program's effects on incarceration, which incapacitated fewer program group members, rather than a direct result of program services.

In contrast to the CEO results, the TJRD programs, for the most part, did not have effects on recidivism. It is unclear exactly why these results are different. If there were a straightforward causal relationship between employment and recidivism, one would expect to see corresponding effects on arrests and other forms of recidivism, at least during the program period when most program group members were working, for both transitional jobs programs. Given that this was not the case, these findings show that simply providing temporary jobs to parolees will not necessarily result in lower recidivism. The pattern of effects suggests that other aspects of the CEO transitional jobs program model, not just the employment itself, are contributing to the effects on recidivism.

There are many possible reasons why CEO may have lowered recidivism when other transitional jobs programs did not. One potential explanation relates to the structure of CEO's transitional jobs component, in which participants are placed in small crews that 
are closely supervised by a CEO staff person. The other transitional jobs programs that were tested did not use this model. It may be that something about the inter-personal dynamic within the crew, or in the relationship between the supervisor and the participants, led to the kind of attitudinal changes that criminologists believe are necessary to lower recidivism. The study did not explicitly test for these effects, but a survey showed that program group members were more likely to report that there was a person in their lives that they could turn to for advice and support.

Criminal justice researchers have argued that employment programs are unlikely to be successful at reducing recidivism unless they address the core criminogenic needs of individuals involved in the criminal justice system. The term "criminogenic needs" is used to describe dynamic (i.e., changeable) risk factors. Most researchers agree that the most important dynamic risk factors are impulsivity, lack of self-control, anti-social cognitions and anti-social peers. These findings have led to a focus on cognitive behavioral therapy (CBT) as a key treatment approach in corrections programing (Lester and Van Voorhis 1997; Hubbard and Latessa 2004). There are many different kinds of CBT interventions, but all share the assumption that the "cognitive distortions" that lead people toward criminal behaviors are learned rather than innate, and thus can be changed. CBT approaches are used to teach offenders new, prosocial skills to replace the antisocial ones they often possess through modeling, practice, and reinforcement (Latessa 2012). Research has further shown that CBT approaches are most effective at reducing recidivism for those at the highest risk of recidivism initially-similar to the earlier findings from the evaluation of the CEO program (Zweig et al. 2011).

As an employment-focused program, CEO did not directly seek to target cognitive behavioral skills in the way that CBT programs do. Nonetheless, it is plausible that the structure of CEO's program, as it sought to improve individual's job readiness through on the job coaching, inadvertently applied similar techniques as those commonly used in CBT programing: pro-social modeling, problem solving skills, and positive reinforcement. This possibility led to the hypothesis described above that CEO's work crew model promoted improvements in attitudes and behaviors and is the mechanism behind CEO's success in reducing recidivism.

In contrast to CEO, none of the TJRD transitional jobs programs operated the work crew model of transitional employment that CEO uses. One site used a scattered-site model, whereby participants were placed individually in jobs with a private (usually nonprofit) employer. Two of the sites were Goodwill Industries affiliates, and participants worked at the program site or in retail locations. The fourth site-the Safer Foundation in Chicago-operated transitional jobs through a contract with a waste management company, and participants all worked at a garbage recycling plant.

Another difference between TJRD and CEO is that the control groups in some of the TJRD sites were offered more intensive job search services, including case management, by programs that specialized in employment services for former prisoners. CEO's control group members were offered only limited assistance with job search, though they could access help in the community. It is possible that the TJRD transitional jobs programs did lead to some reductions in recidivism, but that the relatively substantial programing received by the TJRD control group members also led to such reductions, such that no significant differences were found between program and control group members. In addition, CEO was the only one of the five programs evaluated that 
had extensive experience with both transitional jobs and providing services to former prisoners. In fact, some of the TJRD programs had only recently begun serving the population, and staff were new to the nuances of working with corrections and parole agencies and coping with the special needs of those returning home from prison. Further, some of the TJRD programs had little experience with operating transitional jobs. These sites had the added burden of developing work sites that were suitable for former prisoners.

One thing is clear and consistent across the findings from these and other studies: rates of employment are very low among those returning from prison; less than $30 \%$ of control group members were employed in an average quarter. In both studies, results show that transitional jobs were successful in generating higher rates of employment than would otherwise be found for returning prisoners, demonstrating that when former prisoners are offered an immediate paid job, they are willing to work.

However, since the goal of transitional jobs programs usually moves beyond short-term employment, enhancements to existing transitional job models should be considered. Although the evaluation evidence provides little guidance on what works to increase longer-term employment, it may help to learn from and build on the strategies that were less successful in these programs.

One hypothesis for the lack of consistent employment effects in these studies is that the transitional jobs generally did not train the participants for specific occupations. Another hypothesis is that the transitional jobs were too short and should be extended to allow more time to build a participant's employability before a transition to the regular labor market is considered. However, the evidence from these current studies does not suggest that many participants were terminated from the program because they had hit a time limit. All the programs experienced difficulties in identifying job opportunities in the private sector and in helping participants make the transition to regular employment. Therefore, programs may consider boosting job development and placement services, perhaps by offering incentives to employers or by putting more emphasis on identifying employment opportunities, cultivating partnerships with private employers, and helping participants stay employed once they obtain non-program jobs.

\section{Endnotes}

${ }^{1} \mathrm{CEO}$ is one of four sites in the Enhanced Services for the Hard-to-Employ Demonstration and Evaluation Project, sponsored by the Administration for Children and Families and the Office of the Assistant Secretary for Planning and Evaluation in the U.S. Department of Health and Human Services (HHS), with additional funding from the U.S. Department of Labor.

${ }^{2}$ The Transitional Jobs Reentry Demonstration (TJRD) was funded by the Joyce Foundation, with additional financial support from the JEHT Foundation and the U.S. Department of Labor. The JEHT Foundation ceased operating in January 2009.

${ }^{3}$ In the Detroit site, the transitional jobs program was run by Goodwill Industries of Greater Detroit. In the Minneapolis-St. Paul site, the transitional jobs program was run by Goodwill/Easter Seals Minnesota.

${ }^{4}$ The arrest and conviction data were collected from the following sources: Illinois Criminal Justice Information Authority, Michigan State Police, Minnesota Bureau of Criminal Apprehension, State of Wisconsin Department of Justice, and New York State Division of Criminal Justice Services. 
${ }^{5}$ The state prison data were collected from the following sources: Illinois Department of Corrections, Michigan Department of Corrections, Minnesota Department of Corrections, Wisconsin Department of Corrections, and New York State Division of Criminal Justice Services.

${ }^{6}$ The distinction between prison and jail data is based on agency jurisdiction, admission reason, and level of crime. Specifically, in the states in which these data were collected, those sentenced to more than 12 months are generally sentenced to incarceration in state prison, while those sentenced to 12 months or less are generally sentenced to incarceration in local jails, such as Rikers Island in New York City. Prison sentences usually result from felony convictions while jail sentences usually result from misdemeanor convictions, but individuals can also be sent to either prison or jail because they have violated the terms of their parole or probation conditions. In addition, individuals may be incarcerated in jails without sentences, while they await trial, sentencing, arraignment, or transfer.

${ }^{7}$ The results did not differ substantially across the different sites in the TJRD study. Therefore, for the sake of brevity, we present the full sample results only. See Redcross et al. (2010) for more detailed information about differences across sites.

${ }^{8}$ Data on incarceration in jail were not collected for the TJRD evaluation.

\author{
Abbreviations \\ CBT: Cognitive behavioral therapy; CEO: Center for Employment Opportunities; HHS: U.S. Department of Health and \\ Human Services; TJRD: Transitional Jobs Reentry Demonstration; UI: Unemployment insurance.
}

\title{
Competing interests
}

The IZA Journal of Labor Policy is committed to the IZA Guiding Principles of Research Integrity. The authors declare that they have observed these principles.

\begin{abstract}
Authors' information
Dr. Erin Jacobs Valentine is a Research Associate at MDRC. Her work focuses primarily on evaluations of programs that serve individuals in the criminal justice system, the juvenile justice system, and foster care. Currently, Valentine has a central role in the evaluation of the Youth Villages Transitional Living Program, an intensive program for young adults transitioning out of the foster care or juvenile justice systems in Tennessee. She also has key roles in several prisoner and jail reentry program evaluations, including the National Institute of Justice's Demonstration Field Experiment, the Reintegration of Ex-Offenders Random Assignment Evaluation (which tests programs that have received funding under the national Prisoner Reentry Initiative), and the Second Chance Act Evaluation (which tests adult prison and jail reentry programs). She is also a member of the impact team on the Youth Transition Demonstration, a six-site evaluation of employment services for young people with disabilities. Previously she worked on the Transitional Jobs Reentry Demonstration, a four-state evaluation of transitional jobs programs for men leaving prison, and the Enhanced Services for the Hard-to-Employ Evaluation, which tested service strategies for populations with barriers to employment. Valentine holds a PhD in Sociology from Princeton University.

Cindy Redcross is a Senior Research Associate in MDRC's Health and Barriers to Employment policy area. Her expertise is in random assignment evaluations of programs that serve individuals involved in the criminal justice system. Currently, Redcross is project director for an evaluation of sites replicating the Center for Employment Opportunities' transitional jobs program for former prisoners. She is also project manager on the U.S. Department of Labor's multisite Enhanced Transitional Jobs Demonstration, which targets former prisoners and non-custodial parents, and she has a central role in NIJ's Demonstration Field Experiment: What Works in Reentry Research. Recently, she has served as project manager and research lead for MDRC's prisoner reentry studies, including the Center for Employment Opportunities evaluation, the multisite Transitional Jobs Reentry Demonstration, and the Rikers Island Jail Single Stop evaluation. Since joining MDRC in 1996, she has served as task lead on several large-scale random assignment evaluations. Redcross has led or coauthored a number of published reports and journal articles. She began her career as a researcher for the New York State Assembly. She holds an M.S. in Sociology with a focus on Urban Affairs.
\end{abstract}

\section{Acknowledgements}

The authors would like to thank Dan Bloom and Richard Hendra for their feedback on this paper. We would also like to thank Arielle Sherman, Mariana Veras, and Andrew Rock for their help with this manuscript. We are also grateful to the many other people at MDRC who contributed to the two evaluations on which this paper is based, as well as to the program staff, data providers, and participants who made these evaluations possible. Finally, the authors would like to thank the anonymous referee of this manuscript for the thoughtful review. 
Received: 3 January 2015 Accepted: 29 June 2015

Published online: 27 August 2015

\section{References}

Bernhardt A, Morris M, Handcock M, Scott M (2001) Divergent paths: economic mobility in the new American labor market. Russell Sage, New York

Bloom D (2010) Transitional jobs: background, program models, and evaluation evidence. MDRC, New York

Bushway S, Reuter P (2002) Labor markets and crime risk factors. In: Sherman L, Farrington D, Welsh B, MacKenzie D (eds) Evidence-based crime prevention. Rutledge Press, New York

Carson E, Golinelli D (2014) Prisoners in 2012: trends in admissions and releases, 1991-2012. Bureau of Justice Statistics, Washington, DC

Durose M, Cooper A, Snyder H (2014) Recidivism of prisoners released in 30 states in 2005: patterns from 2005 to 2010. Bureau of Justice Statistics, Washington, DC

Ehrlich I (1973) Participation in illegitimate activities: a theoretical and empirical investigation. J Pol Econ 81(3):521-65

Glaze L, Kaeble D (2014) Correctional populations in the United States, 2013 (Revised). Bureau of Justice Statistics, Washington, DC

Grogger J (1998) Market wages and youth crime. J Lab Econ 16(4):756-91

Hagan J (1993) The social embeddedness of crime and unemployment. Criminology 31(4):465-91

Harlow C (2003) Education and correctional populations. Bureau of Justice Statistics, Washington, DC

Holzer H (2009) The labor market and young black men: updating Moynihan's perspective. Ann Am Acad Pol Soc Sci 621(1):47-69

Holzer H, Raphael S, Stoll M (2004) Will employers hire former offenders?: employer preferences, background checks, and their determinants. In: Pattillo M, Weiman D, Western B (eds) Imprisoning America: the social effects of mass incarceration. Russell Sage, New York

Hubbard D, Latessa E (2004) Evaluation of cognitive-behavioral programs for offenders: a look at outcome and responsivity in five treatment programs. Ohio Office of Criminal Justice Services, Columbus

Jacobs E (2012) Returning to work after prison: final results from the transitional jobs reentry demonstration. MDRC, New York

Latessa $E$ (2012) Why work is important, and how to improve the effectiveness of correctional reentry programs that target employment. Criminol Publ Pol 11(1):87-91

Laub J, Sampson R (2001) Understanding desistance from crime. In: Tonry M (ed) Crime and justice: a review of research. University of Chicago Press, Chicago

Lester D, Van Voorhis P (1997) Cognitive therapies. In: Van Voorhis P, Braswell M, Lester D (eds) Correctional counseling and rehabilitation, 3rd edn., pp 163-85

MDRC (1980) Summary of findings from the national supported work demonstration. MDRC, New York

Morris M, Western B (1999) Inequality in earnings at the close of the twentieth century. Ann Rev of Soc 25(1):623-57

National Research Council (2008) Parole, desistance form crime, and community integration. The National Academies Press, Washington, DC

Pager D (2003) The mark of a criminal record. Am J of Soc 108(5):937-75

Pager D (2007) Marked: race, crime, and finding work in an era of mass incarceration. The University of Chicago Press, Chicago

Petersilia J (2005) From Cell to Society: Who is Returning Home? In: Travis J, Visher C (eds) Prisoner reentry and crime in America. Cambridge University Press, Cambridge, England

Raphael S, Stoll M (2004) The Effect of Prison Releases on Regional Crime Rates. Brookings-Wharton Pap Urb Aff 2004:207-55

Redcross C, Bloom D, Jacobs E, Manno M, Muller-Ravett S, Seefeldt K, Yahner J, Young A Jr, Zweig J (2010) Work after prison: one-year findings from the transitional jobs reentry demonstration. MDRC, New York

Redcross C, Bloom D, Azurdia G, Zweig J, Pindus N (2009) Transitional jobs for ex-prisoners: implementation, two-year impacts, and costs of the center for employment opportunities (CEO) prisoner reentry program. MDRC, New York

Redcross C, Millenky M, Rudd T, Levshin V (2012) More than a job: final results from the evaluation of the center for employment opportunities (CEO) transitional jobs program. MDRC, New York

Sampson R, Laub J (1993) Crime in the making: pathways and turning points through life. Harvard University Press, Cambridge, MA

Stoll M, Bushway S (2008) The effect of criminal background checks on hiring ex-offenders. Crim \& Pub Pol 7(3):371-404

Travis J (2005) But they all come back: facing the challenges of prisoner reentry. Urban Institute, Washington, DC

Uggen C (2000) Work as a turning point in the life course of criminals: a duration model of age, employment, and recidivism. Am Soc Rev 65(4):529-46

Uggen C, Wakefield S, Western B (2005) Work and family perspectives in reentry. In: Travis J, Visher C (eds) Prisoner reentry and crime in America. Cambridge University Press, Cambridge, England

Visher C, Kachnowski V (2007) Finding work on the outside: results from the "Returning Home" project in Chicago. In: Bushway S, Stoll M, Weiman D (eds) Barriers to Reentry? The Labor Market for Released Prisoners in Post-Industrial America. Russell Sage, New York, NY

Warr M (1998) Life-course transitions and desistance from crime. Criminology 36(2):183-216

Weiman D, Stoll M, Bushway S (2007) The regime of mass incarceration: a labor market perspective. In: Bushway S, Stoll M, Weiman D (eds) Barriers to reentry? The labor market for released prisoners in post-industrial America. Russell Sage, New York, NY

Western B, Kling J, Weiman D (2001) The labor market consequences of incarceration. Crim \& Delinq 47(3):410-427 Western B (2006) Punishment and inequality in America. Russell Sage, New York

Western B (2008) From prison to work: A proposal for a national prisoner reentry program. Discussion paper $2008-16$ The Hamilton Project, The Brookings Institution, Washington, DC

Zweig J, Yahner J, Redcross C (2011) For whom does a transitional jobs program work? Examining the recidivism effects of the Center for Employment Opportunities program on former prisoners at high, medium, and low risk of reoffending. Criminol Publ Pol 10(4):945-72 